\title{
PKM Industri Rumah Tangga Kerupuk Tahu Nagih (Enak dan Gurih) di Kelurahan Kemayoran Kecamatan Bangkalan Kabupaten Bangkalan
}

\author{
Nur Aini $\mathbf{S}^{1}$, Ika Lis Mariatun ${ }^{2}$ \\ ${ }^{1}$ Program Studi Pendidikan Matematika,STKIP PGRI Bangkalan-Jln. Soekarno - Hatta No.52 Bangkalan \\ ${ }^{2}$ Program Studi Pendidikan Ekonomi,STKIP PGRI Bangkalan-Jln. Soekarno - Hatta No. 52 Bangkalan \\ E-mail: nuraini.math@gmail.com, No. HP 085755224246
}

\begin{abstract}
ABSTRAK
Salah satu industri pangan yang merupakan industri rumah tangga dalam skala kecil yang banyak berkembang di Indonesia adalah produksi kerupuk. Adapun permasalahan yang dihadapi oleh produsen kerupuk tahu dari segi produksi adalah keterbatasan teknologi dalam pengolahan kerupuk yaitu untuk membuat adonan kerupuk dan memotong kerupuk masih dilakukan secara manual. Selain itu bentuk kerupuk tahu tidak beraturan sehingga terlihat kurang menarik dan tidak bervariasi. Kemasan kerupuk tahu juga masih menggunakan plastik tipis yang diikat dengan tali rafia tanpa ada label kemasan sehingga kerupuk tidak awet dan tidak ada identitas produsen pada kemasan. Dari segi pemasaran, kerupuk tahu hanya dipasarkan terbatas pada warung-warung kecil di sekitar tempat tinggal saja, sehingga hasil penjualan yang diperoleh kurang maksimal. Dari segi manajemen masih belum ada pembukuan tentang biaya produksi dan hasil pendapatan yang diperoleh dari penjualan kerupuk tahu. Berdasarkan permasalahan tersebut, Program Kemitraan Masyarakat (PKM) ini ditujukan untuk meningkatkan dan mengembangkan usaha kerupuk tahu. Hal ini dilakukan dengan tujuan supaya produk kerupuk tahu memiliki nilai jual lebih tinggi daripada sebelumnya, melalui beberapa program kegiatan yang meliputi: (1) penyuluhan pengembangan varian bentuk kerupuk; (2) pelatihan penggunaan mesin pengaduk adonan, mesin pemotong kerupuk, dan mesin Hand Sealer; (3) pelatihan pengemasan dan pemasangan label; (4) pelatihan pemasaran secara online; dan (5) pelatihan manajemen keuangan. Hasil yang telah dicapai dalam PKM ini adalah mitra dapat menerapkan pengetahuan dan teknologi dalam memproduksi kerupuk tahu sehingga pengembangan usaha ini dapat meningkatkan keuntungan yang diperoleh mitra.
\end{abstract}

\section{Kata kunci : kerupuk tahu; peningkatan produksi; PKM}

\section{ABSTRACT}

One of the home industry-based food industries on a small scale is the production of tofu crackers. The problems experienced by partners (Mrs. Hotijeh) in the production aspect of tofu crackers is the limited technologyto make dough crackers and the crackers is still cutting manually. So far, the tofu crackers shape is irregular so this is not good looking and the shape is not variated.Beside that, the packaging of tofu crackers is still using rope and there is no label on the package so the tofu crackers is not crunchy and there is no identity of producer in the product. In the marketing aspect, tofu crackers is only marketed limited to shops on neighborhood, so the profit is not maximum obtained. In the management aspect, there is no accounting system that calculate the cost and income from producing tofu crackers. Based on these problems, the Program Kemitraan Masyarakat (PKM) is intended to improve and develop business tofu crackers. This is done with the aim that tofu cracker products have a higher selling value than previously, through several

Cara Mengutip :Aini, N., Mariatun I. L. (2019). PKM Industri Rumah Tangga Kerupuk Tahu Nagih (Enak dan Gurih) di Kelurahan Kemayoran Kecamatan Bangkalan Kabupaten Bangkalan. JAST : Jurnal Aplikasi Sains dan Teknologi, 3 (2). 107-114. doi:http://dx.doi.org/10.33366/jast.v3i2.1436 
program activities that include:(1) training of development variant of tofu crackers shape; (2) training of using a mixer dough machine, cutting machine, and hand sealer machine; (3) training of packaging and labelling; (4) training of online marketing; and accounting management training.The result has been achieved in this program is the partner can apply knowledge and technology to producing tofu crackers so it can increase the profit of production.

Keywords : tofu crackers; increased production; PKM

\section{PENDAHULUAN}

Salah satu industri makanan yang merupakan home industry atau industi rumah tangga dalam skala kecil adalah produksi kerupuk tahu. Kerupuk tahu adalah kerupuk yang berbahan dasar tahu dan tepung kanji yang rasanya renyah dan gurih. Menurut Purwaningisih [1] tahu merupakan suatu produk yang terbuat dari hasil penggumpalan protein kedelai yang memiliki kandungan protein yang sangat tinggi dan bagus bagi kesehatan. Dengan demikian produk olahan kerupuk tahu ini selain mempunyai rasa yang gurih dan nikmat juga mempunyai manfaat bagi tubuh.

Pada PKM (Program Kemitraan Masyarakat) ini dipilih satu mitra yang memproduksi kerupuk tahu yaitu Ibu Siti Hotijeh yang terletak pada Jl. Pesalakan Gang I RT. 03 RW.04 Kelurahan Kemayoran Kecamatan Bangkalan Kabupaten Bangkalan. Usaha kerupuk tahu yang dijalankan oleh Ibu Siti Hotijeh berjalan sejak tahun 2009 sampai sekarang awalnya hanya dibantu oleh anaknya saja akan tetapi sekarang telah mempunyai 4 orang tenaga kerja yang merupakan ibu-ibu warga sekitar rumah untuk membantu. Perkembangan usaha kerupuk tahu Ibu Siti Hotijeh cukup baik karena permintaan konsumen setiap hari selalu ada. Berdasarkan wawancara yang dilakukan dengan ibu Siti Hotijeh
I. diperoleh informasi bahwa pemasaran dari kerupuk tahu hasil produksinya hanya sebatas pada warung-warung kecil di daerah sekitar rumahnya saja seperti warung nasi goreng, warung bakso, warung nasi pecel dan toko kecil.Selain itu Ibu Siti Hotijeh juga menggelar dagangannya di pasar tradisional yang berada di dekat rumah.

Kerupuk tahu yang dijual ada yang mentah dan ada yang sudah digoreng. Kerupuk mentah dalam kemasan 250 gram dijual dengan harga Rp.25.000,00, sedangkan kerupuk yang sudah digoreng dijual dalam 2 kemasan yaitu dalam kemasan kecil dengan harga Rp.1.000,00 dan kemasan besar Rp.5.000,00. Kelemahan dari kemasan kerupuk tahu ibu Siti Hotijeh ini adalah kerupuk dikemas dengan plastik yang tipis yang diikat dengan tali rafia.

Bahan-bahan untuk membuat kerupuk tahu adalah tahu, tepung kanji, bawang putih, bawang merah, garam dan penyedap makanan.Pada awalnya Ibu Siti Hotijeh mampu memproduksi $15 \mathrm{~kg}$ setiap 3 hari sekali karena keterbatasan alat yang digunakan untuk memproduksi kerupuk tahu.Untuk mengaduk semua bahan, ibu Siti Hotijeh menggunakan alat pengaduk manual dengan menggunakan kayu.Hal ini mengakibatkan tingkat produksi tidak dapat dilakukan secara cepat dan maksimal. 
Proses selanjutnya dalam pembuatan kerupuk tahu ini setelah bahan semua tercampur rata, maka adonan dimasukkan ke dalam kantong plastik kemudian diikat dengan tali rafia. Setelah semua bahan bahan selesai dimasukkan kedalam kantong plastik, maka selanjutnya direbus kedalam air mendidih. Setelah matang bahan kerupuk didiamkan terlebih dahulu sampai dingin kemudian dipotong. Selain proses pengadukan adonan secara manual, proses pemotongan kerupuk juga dilakukan secara sederhana dengan menggunakan pisau. Hal ini menyebabkan hasil pemotongan kerupuk tidak rapi, dan prosesnya agak lama. Kemudian dijemur di panas terik matahari hingga kering, setelah itu proses penggorengan di wajan. Dari hasil penggorengan kerupuk tahu kemudian dikemas didalam plastik biasa diikat dengan tali rafia sehingga kerupuk tahu tidak awet.

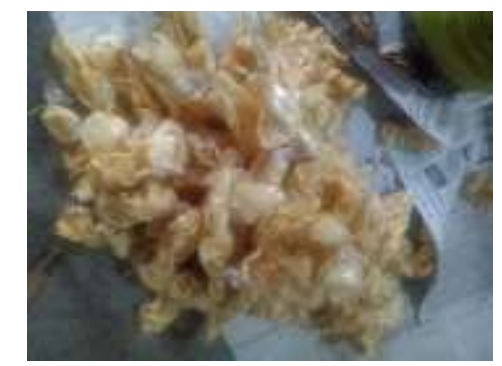

Gambar 1. Bentuk dan Kemasan Kerupuk

Cara pengemasan produk kerupuk tahu Ibu Hotijeh yang sangat sederhana dan tanpa adanya label membuat tampilan produk kerupuk tahu kurang menarik. Untuk itu perlu adanya perbaikan dari segi pengemasan (bentuk kemasan, bahan kemasan, dan label kemasan). Sebab menurut hasil penelitian Mufreni [2] menunjukkan bahwa desain produk, bentuk kemasan, dan bahan (material kemasan) berpengaruh signifikan terhadap minat beli konsumen.

Dari aspek manajemen, usaha kerupuk tahu ibu Siti Hotijeh adalah usaha rumah tangga yang dilakukan secara sederhana sehingga dalam hal keuangan usaha tidak dicatat dalam pembukuan. Menurut Gunawan [3], perusahaan yang menghasilkan suatu produk dalam proses produksinya memerlukan informasi mengenai berapa besar jumlah biaya yang digunakan dalam menghasilkan produk-produk tersebut dan sekaligus diharapkan dapat menghitung dan menentukan harga pokok penjualan yang tepat dan produk yang dihasilkan. Tujuan utama suatu perusahaan didirikan selain untuk memenuhi kebutuhan manusia adalah untuk mendapatkan keuntungan yang layak. Ibu Siti Hotijeh berharap agar dapat membuat pembukuan keuangan usaha dengan baik agar dia mengetahui tentang arus dana yang dikeluarkan untuk biaya bahan baku maupun untuk proses produksi baik pengeluaran untuk tenaga kerja, maupun biaya untuk pengiriman kerupuk tahu ke tempat pemasaran. Disamping itu, dengan pembukuan keuangan usaha akan memudahkan untuk mengetahui keuntungan yang diperoleh setiap bulan.

Selain itu, dalam hal manajemen pemasaran untuk saat ini pemasaran kerupuk tahu hanya sebatas warungwarung di sekitar rumah ibu Siti Hotijeh. Dia berharap agar kerupuk tahu hasil produksinya dapat bersaing dengan produk lokal lainnya dan dapat dipasarkan di tempat yang lebih meluas lagi seperti pada pusat oleh-oleh khas 
madura ataupun di tempat-tempat wisata. Mitra juga berharap dapat memasarkan produknya melalui media online. Pemasaran melalui media online (emarketing) merupakan suatu proses pemasaran yang menggunakan internet dimana konsumen dapat memperoleh informasi melalui produk, melakukan transaksi jual beli dan mempromosikan produk yang telah dikomsumsi oleh konsumen, bahkan turut serta mempromosikan penjual atau perusahaan yang produknya telah dibeli oleh konsumen [4]. Media online yang dapat digunakan untuk pemasaran adalah media sosial (facebook, instagram, dan whatsapp, dan lain sebagainya). Dengan adanya pemasaran melalui sosial media, pertukarang informasi antara pembeli dan penjual dalam berbagi informasi dapat menjadi lebih mudah [5].

\section{METODE KEGIATAN}

Solusi yang dapat dilakukan untuk membantu mitra dalam menyelesaikan permasalahan produksi kerupuk tahu adalah dengan diadakannya penyuluhan pengembangan varian bentuk kerupuk, pelatihan penggunaan mesin pengaduk adonan dan mesin pemotong kerupuk, pelatihan pemasangan label, pelatihan pemasaran secara online melalui media sosial, serta pelatihan manajemen keuangan.

Adapun metode yang dilakukan melalui beberapa tahapan sebagai berikut:

\section{Tahap Persiapan}

Pada tahap persiapan, tim pengabdian masyarakat berkoordinasi dengan mitra untuk mempersiapkan segala sesuatu yang akan digunakan dalam kegiatan.

\section{Tahap Pelaksanaan}

Pada tahap ini dilakukan penyuluhan atau transfer ilmu mengenai pentingnya berinovasi dalam mengembangkan usaha produk kerupuk tahu. Pengembangan produk adalah suatu proses penemuan ide untuk barang dan jasa termasuk merubah, menambah atau merumuskan kembali sebagian dari sifat-sifat pokok yang sudah ada dalam segi corak, merek dan kuantitas [6]. Hal ini dilakukan untuk memberikan gambaran kepada mitra akan pentingnya variasi bentuk produk kerupuk tahu serta pentingnya pengemasan yang baik dan menarik. Mitra diberi gambaran empat macam varian bentuk kerupuk tahu yaitu bulat kecil, bulat besar, kotak dan bentuk lonjong.

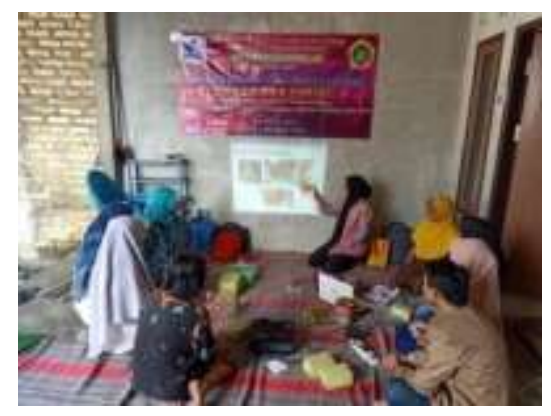

Gambar 2. Pelatihan Pengembangan Variasi Bentuk Produk Kerupuk Tahu.

Setelah itu mitra diberi pelatihan cara menggunakan mesin pengaduk adonan dan mesin pemotong kerupuk. Kemudian mitra diberi pelatihan mengenai bagaimana cara pengemasan kerupuk tahu yang baik menggunakan mesin hand sealer dan diberi label yang menarik pada kemasan. Selanjutnya mitra diberi pelatihan tentang cara memasarkan produk secara online melalui media sosial. Dan yang terakhir adalah mitra diberi pelatihan manajemen keuangan. 
Hal ini dilakukan dengan tujuan agar mitra mengetahui perhitungan biaya produksi dan laba, sehingga mitra dapat menentukan harga jual. Selain itu mitra juga dapat mengetahui aliran kas keluar dan kas masuk setiap harinya.

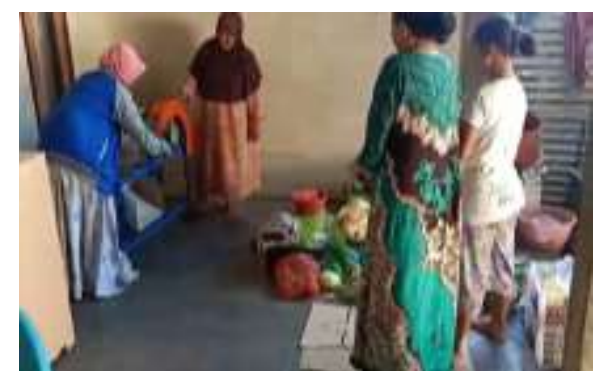

Gambar 3. Pelatihan Penggunaan Mesin

3. Tahap Pendampingan

Pada tahap ini dilakukan pendampingan terhadap mitra dalam menerapkan ilmu pengetahuan dan teknologi yang telah diperoleh untuk mengembangkan usahanya. Mitra dipersilahkan untuk mempraktikkan membuat adonan kerupuk tahu dengan empat macam varian bentuk yaitu bulat kecil, bulat besar, kotak dan bentuk lonjong. Pembuatan adonan kerupuk ini menggunakan mesin pengaduk adonan yang telah disediakan. Pemotongan kerupuk juga menggunakan mesin pemotong kerupuk.

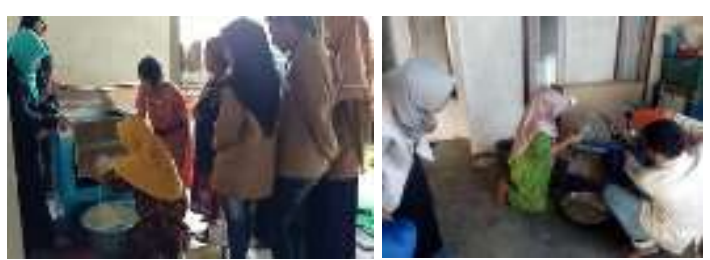

Gambar 4. Kegiatan Pembuatan Kerupuk Tahu

Pada hari berikutnya, mitra melakukan praktik pengemasan produk dengan menggunakan mesin hand sealer dan juga memasang label pada kemasan produk kerupuk tahu.

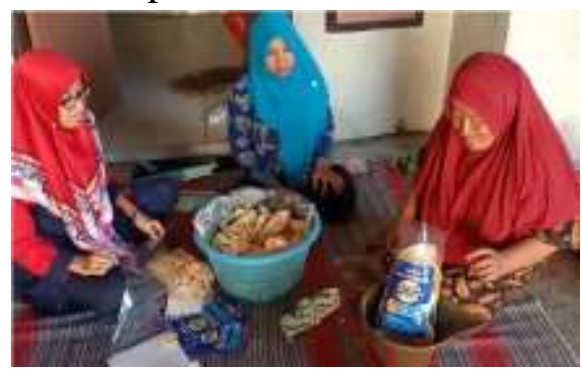

Gambar 5. Kegiatan Pengemasan dan Pelabelan

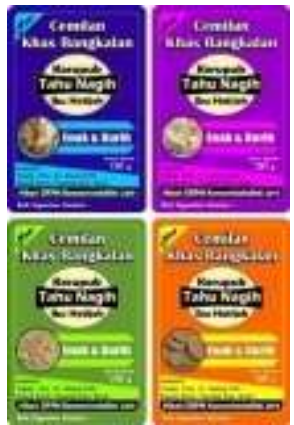

Gambar 6. Label Kemasan Kerupuk Tahu

4. Tahap Pelatihan Manajemen

Pelatihan manajemen keuangan dilakukan agar mitra dapat menyusun laporan keuangan sederhana untuk meningkatrkan kemampuan dalam mengelola keuangan. Dengan pelatihan ini mitra dapat megetahui perhitungan biaya produksi dan laba, sehingga mitra dapat menentukan harga pokok penjualan.Selain itu mitra juga dapat mengetahui aliran kas keluar dan kas masuk setiap harinya. Berdasarkan laporan keuangan yang baik diharapkan mitra dapat merencanakan pengembangan modal usahanya.

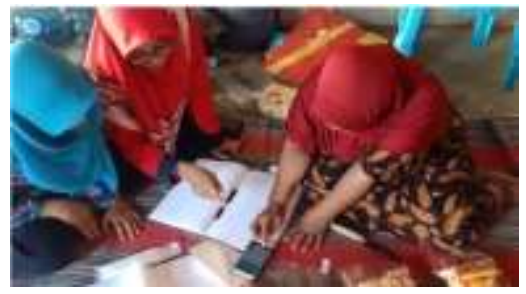

Gambar 7. Pelatihan Pembukuan Keuangan 


\section{KARYA UTAMA}

Dalam Program Kemitraan Masyarakat ini hasil yang dikembangkan adalah berupa "Kerupuk Tahu Nagih" (Enak dan Gurih) dengan beragam varian bentuk dan pengemasan yang lebih baik dan lebih menarik daripada sebelumnya.

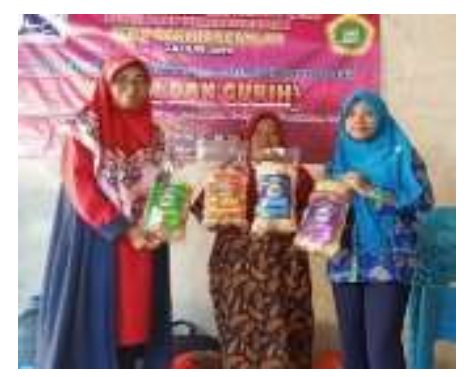

Gambar 8. Hasil Produk Kerupuk Tahu Nagih

Dalam memproduksi Kerupuk Tahu Nagih ini digunakan mesin pengaduk adonan dan mesin pemotong kerupuk sehingga mitra dapat memproduksi kerupuk tahu sampai dengan $15 \mathrm{~kg}$ tiap sekali produksi dan menghasilkan kurang lebih 75 bungkus kerupuk tahu dengan berat bersih 250 gr/kemasan.

\section{ULASAN KARYA}

Hasil produksi Kerupuk Tahu Nagih memiliki kualitas yang lebih baik dari sebelumnya. Adapun karakteristik Kerupuk Tahu Nagih antara lain :

1. Proses pembuatannya menggunakan mesin pengaduk adonan dan mesin pemotong kerupuk.

2. Memiliki 4 (empat) macam varian bentuk yaitu bulat kecil, bulat besar,kotak, dan lonjong.

3. Proses pengemasan menggunakan plastik tebal dan dipress menggunakan mesin hand sealer sehingga kerenyahan kerupuk tahu tetap terjaga (awet).

4. Adanya label pada kemasan yang merupakan identitas produsen. Label ini didisain dengan 4 macam warna yaitu warna hijau untuk bentuk bulat kecil, warna jingga untuk bentuk bulat besar, warna ungu untuk bentuk kotak, dan warna biru untuk bentuk lonjong.

\section{DAMPAK DAN MANFAAT KEGIATAN}

Adanya Program Kemitraan Masyarakat ini memberikan dampak serta manfaat kepada mitra. Adapun dampak serta manfaat yang diterima secara langsung yaitu :

1. Mitra dapat menggunakan semua mesin sehingga produksi kerupuk tahu meningkat.

2. Sebelumnya mitra hanya mampumemproduksi kerupuk $5 \mathrm{~kg}$ dalam sekali produksi, kini mitra mampu memproduksi kerupuk sampai dengan $15 \mathrm{~kg} /$ sekali produksi

3. Mitra dapat berinovasi mengembangkan bentuk kerupuk lebih bervariasi, yang sebelumnya bentuk kerupuk tidak beraturan, kini ada 4 macam bentuk yaitu bulat kecil, bulat besar, kotak, dan lonjong.

4. Mitra dapat melakukan pengemasan kerupuk tahu menggunakan plastik tebal dan mesin hand sealer sehingga kerenyahan kerupuk tahu tetap terjaga (awet).

5. Adanya label pada kemasan membuat tampilan kemasan kerupuk tahu lebih menarik dan ada identitas produsen. 
6. Mitra dapat memasarkan hasil produksi kerupuk tahu secara online melalui media sosial facebook, instagram, dan whatsapp.

7. Mitra dapat melakukan pembukuan keuanganusaha yang meliputi biaya produksi, menghitung laba, menentukan harga jual, sampai dengan mencatat penerimaan kotor (omset) penjualan setiap harinya.

8. Kegiatan ini dapat meningkatkan penghasilan mitra. Hal ini dapat dilihat dari penerimaan kotor per produksi rata-rata mencapai Rp.750.000 yang sebelumnya hanya mencapai rata-rata Rp.125.000 per sekali produksi.

\section{KESIMPULAN}

Berdasarkan hasil pelaksanaan Program Kemitraan Masyarakat dapat disimpulkan bahwa:

1. Dengan adanya mesin pengaduk adonan, alat pemotong kerupuk, dan alat pengepres plastik kemasan dapat meningkatkan kuantitas hasil produksi kerupuk tahu nagih yang awalnya $5 \mathrm{~kg} / \mathrm{hari}$ menjadi 15 $\mathrm{kg} / \mathrm{hari}$.

2. Ada peningkatan kualitas produk kerupuk tahu yang dapat dilihat dari bentuk kerupuk dan cara pengemasan.

3. Bentuk kerupuk yang sebelumnya tidak beraturan, kini lebih bervariasi yaiu bulat kecil, bulat besar, kotak, dan lonjong sehingga terlihat lebih menarik

4. Cara pengemasan kerupuk tahu lebih baik dari sebelumnya sehingga kerenyahan kerupuk tahu tetap terjaga. Selain itu juga adanya label pada kemasan membuat produk kerupuk tahu nagih memiliki identitas produsen dan tampilan yang menarik.

5. Pemasaran produk tidak hanya terbatas pada toko-toko saja, tetapi telah menggunakan media sosial. Hal ini berpengaruh pada peningkatan hasil pendapatan mitra setiap harinya.

6. Mitra dapat melakukan pembukuan sederhana tentang keuangan usaha meliputi biaya produksi, menghitung laba, menentukan harga jual, sampai dengan mencatat penerimaan kotor (omset) penjualan setiap harinya

\section{PENGHARgaAN}

Ucapan terima kasih disampaikan kepada DRPM Kemenristekdikti, Ibu Hotijah Sebagai Mitra Kerja, Bapak Didik Hermanto, S.T, M.Pd Sebagai Ketua STKIP PGRI Bangkalan, LPPM STKIP PGRI Bangkalandan semua pihak yang telah membantu pelaksanaan Program Kemitraan Masyarakat ini.

\section{DAFTAR PUSTAKA}

[1] Purwaningsih, Eko. 2015. Cara Pembuatan Tahu dan Manfaat Kedelai. Ganeca Exact. Bekasi

[2] Mufreni, Alfin. 2016. Pengaruh Desain Produk, Bentuk Kemasan dan Bahan Kemasan Terhadap Minat Beli Konsumen (Studi Kasus Teh Hijau Serbuk Tocha). Jurnal Ekonomi Manajemen Vol.2 No.2 Hal. 48-54. November 2016. 
[3] Gunawan, Candra. 2017. Penentuan Harga Jual Produk Menggunakan Metode Cost-Plus Pricing Dengan Pendekatan Variabel Costing Pada UKM Pia Latief Kediri. Simki-Economic Vol. 01 No. 9 Tahun 2017

[4] Mardiani, Iin, dkk. 2013. Analisis Keputusan Pembelian Konsumen Melalui Media Online (E-Marketing). Jurnal Ekonomi Vol.4 No.2, November 2013.

[5] Moriansyah, La. 2015. Pemasaran Melalui Media Sosial: Antecedents dan Consequences. Jurnal Penelitian Komunikasi dan Opini Publik Vol.19 No.3 Hal. 187-196 Desember 2015.

[6] Rini, Endang S. 2013. Peran Pengembangan Produk dalam Meningkatkan Penjualan. Jurnal Ekonom, Vol 16 No. 1 Januari 2013 